九州大学学術情報リポジトリ

Kyushu University Institutional Repository

\title{
A ribonuclease from UV-induced mutant of
} Rhizopus niveus

Koga, Katsumi

Laboratory of Sericulture Chemistry, Faculty of Agriculture, Kyushu University

Mukai, Jun-Ichiro

Laboratory of Sericulture Chemistry, Faculty Of Agriculture, Kyushu University

Akune, Satoru

Laboratory of Sericulture Chemistry, Faculty Of Agriculture, Kyushu University

https://doi.org/10.5109/22741

出版情報: 九州大学大学院農学研究院紀要. 13 (4)，pp.711-727，1966-02. Kyushu University バージョン：

権利関係 : 
Journal of the Faculty of Agriculture, Kyushu University, Vol. 13, No. 4, February 15, 1966

\title{
A ribonuclease from UV-induced mutant of Rhizopus niveus
}

\author{
Katsumi KogA, Jun-Ichiro Mukai and Satoru AKUNE*
}

Ribonucleascs (RNases) with strict specificities are useful for the determination of nucleotide sequences of ribonucleic acid (RNA), since they quantitatively hydrolyze certain phosphodiester bonds in a polynucleotide chain. Pancreatic RNase I has specificity for pyrimidine nucleotide diester bonds, ${ }^{6}$ ) while Aspergillus oryzae RNase $\mathrm{T}_{1}$ from Takadiastase possesses specificity for guanylic acid. ${ }^{17,28,32,33,36}$, Some of the RNases from leaves, ${ }^{15,25,35,39)}$ animals, ${ }^{7,11,16,26,41)}$ and microbes $8,10,18,19,20,21,23,29,30,31,37)$ are of the RNase I type ${ }^{11)}$ or $T_{1}$ type, ${ }^{8,31,37)}$ but no RNases with a specificity different from these two have been obtained thus far. It is, therefore, worthwhile to seek RNase of a new type, and easily available sources are desired for this purpose. "Glutase," a commercially obtainable (Hankyu Enzyme Co. Ltd.) preparation from UV-induced mutant of Rhizopus niveus, is a good source of RNase.

Systematic screening tests of nucleases of microbes have been studied by several groups of investigators,, 1018 19,23 31,37) and according to Nakao and Ogata, ${ }^{18)}$ an extracellular enzyme system of Rhizopus niveus degraded RNA completely at pH 5, liberating 2'(3')-nucleotides and inorganic phosphate. But, no purification of Rhizopus RNase has ever been attained. This experiment is devoted to the purification of Rhizopus RNase from "Glutase" and the determination of its specificity. A preliminary study showed no strict specificity of the enzyme at least as to the nucleotide diester split. Further purification and characterization are in progress.

* Laboratory of Sericultural Chemistry, Agricultural Chemistry Institute, Kyushu University. 


\section{EXPERIMEN'TAL}

\section{Starting material}

"Glutase" was kindly supplied by Mr. Naosuke Takagi of Hankyu Enzyme Co. Ltd. It was the commercial product prepared as follows: the filtrate of water extract of Koji (Rhizopus niveus irradiated with UV) was brought to $\mathrm{pH} 6.2$ by $\mathrm{Ca}(\mathrm{OH})_{2}$ and filtered. The filtrate was adjusted to 0.72 sat. with solid ammonium sulfate and the precipitate (Glutase) was collected by filtration.

\section{RNA}

Commercial yeast RNA (N. B. C. or Sigma, as available) was deproteinized by the method of Sevag ${ }^{34)}$ and extensively dialyzed against $1 \mathrm{M} \mathrm{NaCl}$ and finally against water. To the dialysate sodium acetate ( $2 \%$, final) and 2 vols. of cold ethanol were added. The precipitate was collected by centrifugation and dried in a vacuum desiccator.

\section{RNase assay}

An assay mixture contained $0.2 \mathrm{ml}$ of appropriately diluted enzyme solution, $0.25 \mathrm{ml}$ of $0.2 \mathrm{M}$ sodium acetate buffer, $\mathrm{pH} 5.3,0.3 \mathrm{ml}$ of water, and $0.25 \mathrm{ml}$ of RNA solution ( $12 \mathrm{mg}$ per $\mathrm{ml}$ of water). Incubation was carried out at $37^{\circ} \mathrm{C}$ for $15 \mathrm{~min}$. The reaction was stopped by the addition of $0.2 \mathrm{ml}$ of uranium reagent $(25 \%$ and $0.75 \%$ with respect to perchloric acid and uranium acetate respectively). After $30 \mathrm{~min}$ at room temperature, the precipitate was removed by centrifugation, 0.2 $\mathrm{ml}$ of the supernatant was diluted with $4.8 \mathrm{ml}$ of water, and $\mathrm{OD}_{260 \mathrm{~m} u}$ was determined against the proper blank. If necessary, the enzyme was diluted by $0.2 \mathrm{M} \mathrm{NaCl}$. The $\mathrm{OD}_{260 \mathrm{~m} \mu}$ value in relation to enzyme concentration was linear up to approx. 0.6 when the crude extract was used (Fig. 1, left). The purest fraction gave the same linearity, but deviation of the value was a little pronounced (Fig. 1, right). One unit of activity was defined as the increase in $\mathrm{OD}_{260 \mathrm{~m},}$ of 1.0 , and specific activity as (units per $0.2 \mathrm{ml}$ of the properly diluted enzyme) $\times 5 /\left(E_{280}\right.$ of the enzyme used $)$.

\section{Assay of contaminating and possibly interfering enzymes}

Nonspecific PDase and PMase were determined, using Ca-bis(paranitrophenyl) phosphate and Na-para-nitrophenyl phosphate as substrate respectively.4) The $3^{\prime}\left(2^{\prime}\right)$-nucleotidase was assayed with adenylic acid.) DNase activity was tested by the practically identical method as the RNase assay.

\section{Chloride Concentration}

The titration method by Mohr ${ }^{12}$ ) was applied. 

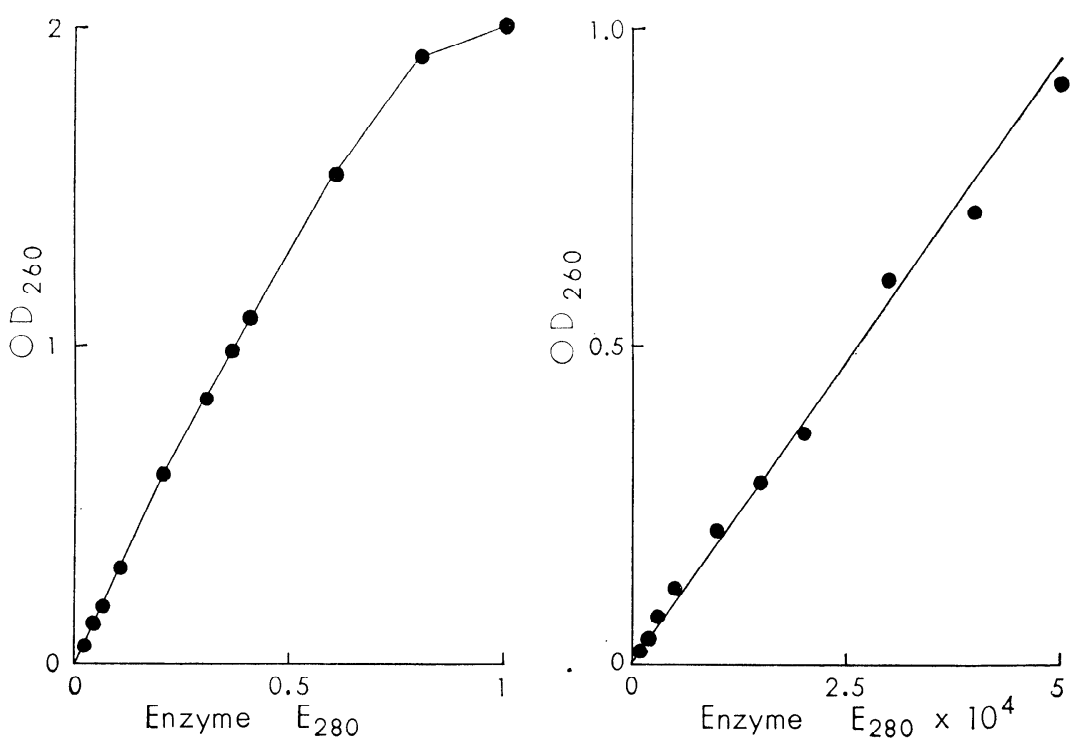

Fig. 1. Effect of enzyme concentration on the RNase activity. The sample was the crude extract (left), and the purest fraction (right). Both were diluted with $0.2 \mathrm{M} \mathrm{NaCl}$ to attain proper concentrations, which were expressed as $\mathrm{E}_{280}$. The assay method was describcd in "Experimental."

\section{Solvents for paper chromatography and paper electrophoresis}

Solvent 1 , isopropanol : $1 \mathrm{M}$ sodium acetate : sat. ammonium sulfate $(2: 20: 80 \mathrm{v} / \mathrm{v} / \mathrm{v}) .{ }^{14)} \quad$ Solvent 2, isopropanol : water $(70: 30 \mathrm{v} / \mathrm{v})$ with $0.35 \mathrm{ml}$ of $\mathrm{NH}_{4} \mathrm{OH}$ per liter of gas space. ${ }^{14)}$ Solvent $3,0.084 \mathrm{M}$ formic acid was adjusted to $\mathrm{pH} 2.7$ by $\mathrm{NH}_{4} \mathrm{OH} .{ }^{27)}$ Solvent 4 , tert-butanol : Solvent 3 adjusted to $\mathrm{pH} 3.8$ by $\mathrm{NH}_{4} \mathrm{OH}(50: 50 \mathrm{v} / \mathrm{v}) .^{27)}$

\section{Mapping procedure of RNase digest}

The procedure was essentially according to Rushizky and Knight.27) Filter paper (Toyoroshi No. 51) was placed in the electrophoresis cabinet and moistened with Solvent 3. After the voltage to be used was applied for $30 \mathrm{~min}$, an aliquot of the RNase digest of RNA was applied at a cathode corner of the paper. Picric acid, as a marker, was applied at the opposite corner of the cathode side. After 15 hours' run with $6 \mathrm{~V}$ per $\mathrm{cm}$ and 4 to $5 \mathrm{ma}$, the paper was dried. and chromatographed to the perpendicular direction in Solvent 4 (Fig. 11, top). The spots were detected under Manaslu UV Light, and eluted with water. Aliquots of the water-eluted substances were treated with $0.1 \mathrm{~N} \mathrm{HCl}$ for 4 hours at room temperature. Other aliquots were treated with $0.3 \mathrm{~N} \mathrm{NaOH}$ for 18 hours at $37^{\circ} \mathrm{C}$. The treated substances, 
together with untreated aliquots of the water eluates, were simultaneously chromatographed in Solvent 1 (Fig. 11, bottom). The separated compounds werc eluted with $0.1 \mathrm{~N} \mathrm{HCl}$ and identified by the ultraviolet absorption spectra. ${ }^{2)}$

\section{Purification of Rhizopus RNase}

Step 1-To $500 \mathrm{~g}$ of Glutase 2.5 liters of $0.2 \mathrm{M} \mathrm{NaCl}$ were added and the suspension was filtered through a Büchner funnel. The filtrate was brought to 0.35 sat. with solid ammonium sulfate and held $30 \mathrm{~min}$ at room temperature. The precipitate was removed by centrifugation and the supernatant was adjusted to 0.70 sat. with solid ammonium sulfate and settled overnight at $5^{\circ} \mathrm{C}$.

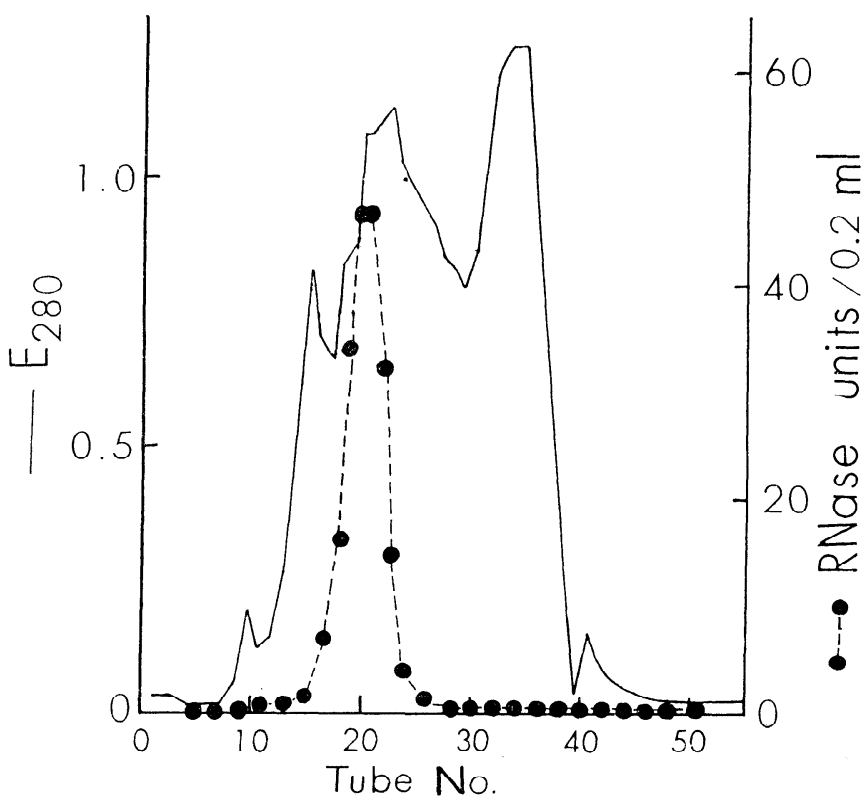

Fig. 2. Step 4 of the purification procedure. Gel filtration through a Scphadex G-100 (Pharmacia) column $(3 \times 36 \mathrm{~cm})$. The sample was $2.7 \mathrm{ml}$ of the trichloroacetic acid soluble fraction. Total $\mathrm{E}_{280}$ applied, 194; yield, $75 \%$; flow rate, $30 \mathrm{ml}$ per hour, about $6 \mathrm{ml}$ per tube. The eluant, $0.05 \mathrm{M}$ ammonium acetate buffer, pH 6 .

Step 2-The precipitate was collected by centrifugation and taken

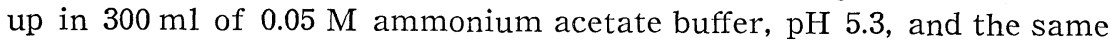
vol. of ice-cold acetone was slowly added with stirring. After 30 min at $0^{\circ} \mathrm{C}$, the precipitate was collected by centrifugation and taken up in $100 \mathrm{ml}$ of water.

Step 3-The solution was acidified with ice-cold $10 \%$ trichloroacetic 
acid $^{24}$ ) to $\mathrm{pH} 2$ (final concn., approx. $1.5 \%$ ). After 30 min at $0^{\circ} \mathrm{C}$, the suspension was centrifuged and the precipitate was discarded. The supernatant was neutralized with $\mathrm{N} \mathrm{NaOH}$.

Step 4-The solution in several portions was filtered through a Sephadex G-100 column in equilibrium with $0.05 \mathrm{M}$ ammonium acetate buffer, pH 6.0 (Fig. 2).

Step 5-The filtrates of 11 experiments were pooled and chromatographed on an ECTEOLA-cellulose column (Fig. 3). The curve of the specific activity indicates the presence of impurity. The contents of tubes 181 to 186 were pooled and processed further.

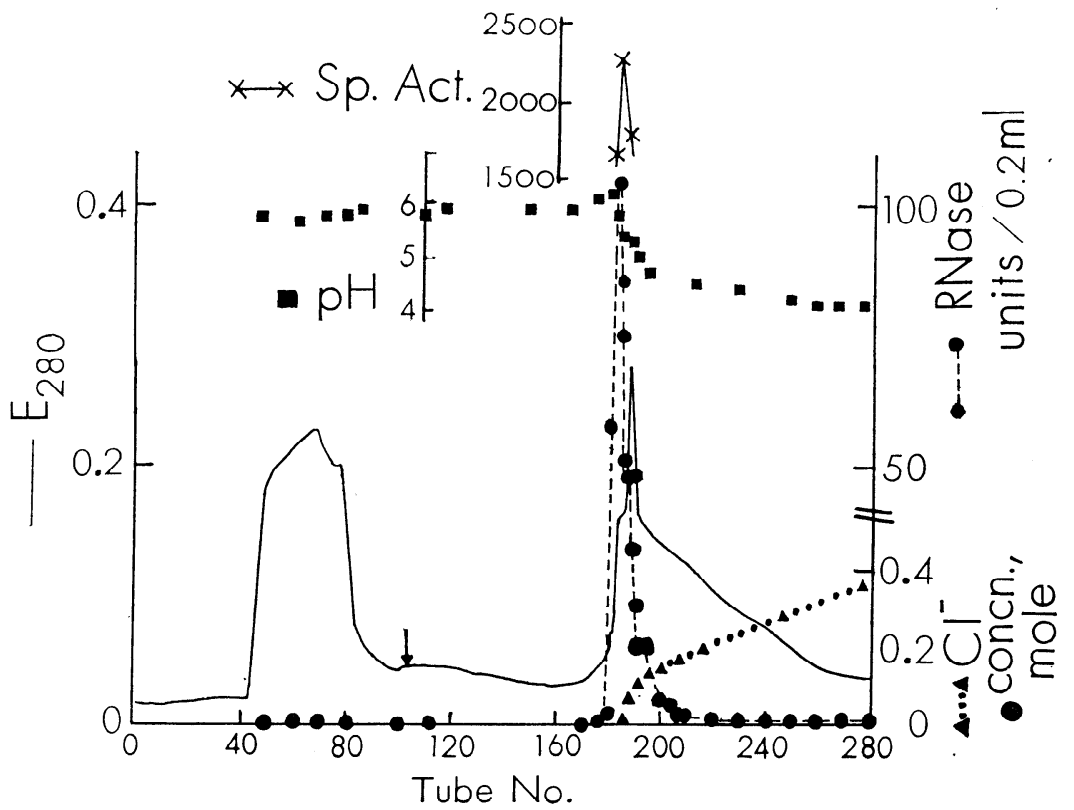

Fig. 3. Step 5 of the purification procedure. Chromatography on an ECTEOLAcellulose $($ Brown $)$ column $(3 \times 44 \mathrm{~cm})$. The sample, $200 \mathrm{ml}$ of the Sephadex G-100 filtrate, total $E_{230}$ applied, 166 ; yield, $90 \%$. Elution was initiated with $0.05 \mathrm{M}$ ammonium acetate buffer, $\mathrm{pH}$ 6. After the break-through peak (tubes 41 to 93) was collected, a linear gradient with each $300 \mathrm{ml}$ of the starting buffer and $0.1 \mathrm{M}$ ammonium acetate buffer, $\mathrm{pH} 3$, containing $0.5 \mathrm{M} \mathrm{NaCl}$ was started (at the arrow). Flow rate, 20 to $30 \mathrm{ml}$ per hour, about $6 \mathrm{ml}$ per tube.

Step 6-Five batches, carried through Step 5, were combined, lyophilized and dialyzed through fish skin against $0.005 \mathrm{M}$ Tris- $\mathrm{HCl}, \mathrm{pH} 7.5$. No loss of activity was observed after lyophilization and dialysis. The dialysate was applied on a Dowex 2 column. A linear gradient elution resulted in poor separation (Fig. 4), giving little information about the homogeneity of the enzyme. 


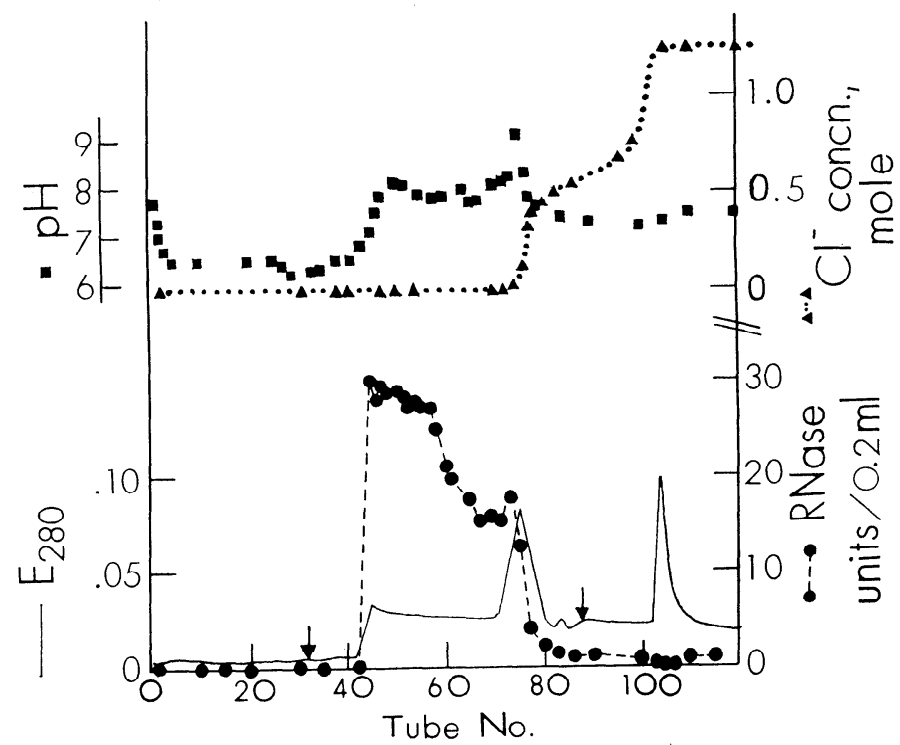

Fig. 4. Stcp 6 of the purification procedure. Dowex 2 resin chroma tography. The column $(0.9 \times 40 \mathrm{~cm})$ was previously equilibrated with $0.1 \mathrm{M}$ ammonium acetate buffer, $\mathrm{pH}$ 8.0. The sample was the ECTEOLA-cellulose fraction dialyzed against $0.005 \mathrm{M}$ Tris-HCl, $\mathrm{pH}$ 7.5. A linear gradient elution was initiated at the first arrow, with each

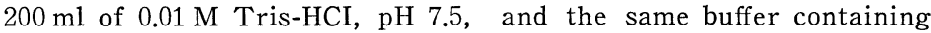
$0.5 \mathrm{M} \mathrm{NaCl}$. The second arrow shows the stepwise elution by the Tris buffer containing $1 \mathrm{M} \mathrm{NaCl}$. Total $\mathrm{E}_{280}$ applied, 17 (in $160 \mathrm{ml}$ ); recovery, $70 \%$. Flow rate, $2.5 \mathrm{ml}$ per hour, about $6 \mathrm{ml}$ per tube.

Step 7-Contents of tubes 43 to 65 (Fig. 4) were pooled, lyophilized and filtered through a Sephadex G-25 column $(2.2 \times 50 \mathrm{~cm})$ for desalting. Eluant was $0.01 \mathrm{M}$ ammonium acetate buffer, $\mathrm{pH} 5.3$, containing 0.05 $\mathrm{M} \mathrm{NaCl}$.

Step 8-To check the homogeneity, the emuent of Step 7 was lyophilized, and the residue was dissolved in $0.8 \mathrm{ml}$ of water, and filtered through a Sephadex G-100 column $(0.66 \times 99 \mathrm{~cm})($ Fig. 5). The abnormal base line of protein and a shoulder at the descending side of the peak suggested that the enzyme was still not pure. An ammonium sulfate marker also appeared at nearly the same place as the peak, so the enzyme was likely retained in the G-100 matrix. Further experiments with G-75 or G-50 are needed. The inconsistency of the results with the previous data (Step 3, Fig. 2) indicates that the enzyme had probably formed some stable complex in the earlier stage.

The units and $E_{280}$ at each step were listed in Table 1. 


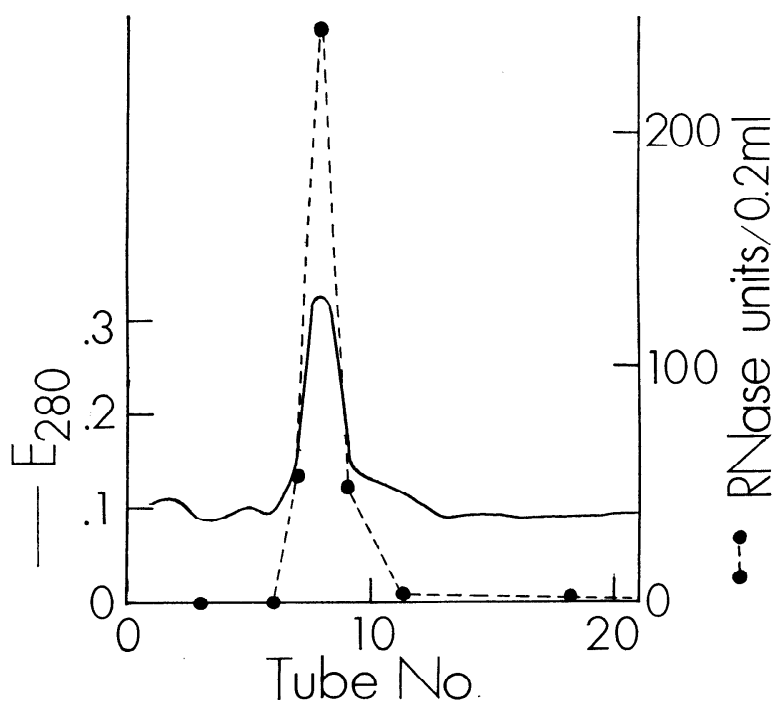

Fig. 5. Step 8 of the purification procedure. Analytical gel filtration through a Sephadex G-100 column $(0.66 \times$ $99 \mathrm{~cm})$. The sample was the lyophilized residue of the Sephadex G-25 effluent, dissolved in $0.8 \mathrm{ml}$ of water. Total $E_{280}$ applied, 1.6 ; recovery, $85 \%$. Flow ratc, $2.7 \mathrm{ml}$ per hour, about $3 \mathrm{ml}$ per tube. The eluant applied was $0.01 \mathrm{M}$ ammonium acetate buffer, $\mathrm{pH} 5.3$, containing $0.5 \mathrm{M} \mathrm{NaCl}$.

Table 1. Summary of purification procedure. For the definition of enzyme units, and specific activity, see "Experimental."

\begin{tabular}{|c|c|c|c|c|c|}
\hline Step & Vol., ml & $\begin{array}{l}\text { Total } \\
\mathrm{E}_{280}\end{array}$ & $\begin{array}{l}\text { Total } \\
\text { units }\end{array}$ & $\begin{array}{l}\text { Specific } \\
\text { activity }\end{array}$ & $\begin{array}{l}\text { Activity } \\
\text { yield, } \%\end{array}$ \\
\hline Crude extract & 2,230 & 203,000 & 190,000 & 4.7 & 100 \\
\hline $\begin{array}{l}\text { 1. } 0.35-0.70 \text { sat. ammonium } \\
\text { sulfate (ppt) }\end{array}$ & 300 & 39,000 & 85,000 & 11 & 45 \\
\hline 2. $50 \%$ acetone $(\mathrm{ppt})$ & 108 & 8,000 & 80,000 & 48 & 42 \\
\hline $\begin{array}{l}\text { 3. } 1.5 \% \text { trichloroacetic } \\
\text { acid (supernatant) }\end{array}$ & 150 & 4,800 & 75,000 & 78 & 39 \\
\hline 4. Sephadex G-100 filtrate ${ }^{a}$ & 610 & 560 & 29,000 & 260 & 25 \\
\hline 5. ECTEOLA-cellulose fraction ${ }^{b}$ & 169 & 17 & 3,600 & 1,000 & $10^{\mathrm{c}}$ \\
\hline 6. Dowex 2-resin fraction & 113 & 3.1 & 2,800 & 4,600 & 8 \\
\hline Lyophilized & 5.2 & 3.4 & 2,100 & $3,100^{\AA}$ & 6 \\
\hline 7. Sephadex G-25 filtrate & 70 & 1.8 & 1,800 & 5,200 & 5 \\
\hline Lyophilized & 0.8 & 1.6 & 1,100 & $3,400^{d}$ & 3.2 \\
\hline 8. Sephadex G-100 filtrate & 3.1 & 0.71 & 780 & 5,400 & 2.3 \\
\hline
\end{tabular}

a,b Composites of 11 and 5 experiments respectively.

c Recalculated as if the whole fractions were processed in one batch.

d Accurate determination of the activity is difficult after lyophilization owing to the high dilution (2000 times or so) required for the routine assay. 


\section{REsUlts}

\section{Properties of Rhizopus RNase}

The ultraviolet spectrum of the purest fraction (Step 8) was shown in Fig. 6. The optimum pH for both the crude and the purest enzyme

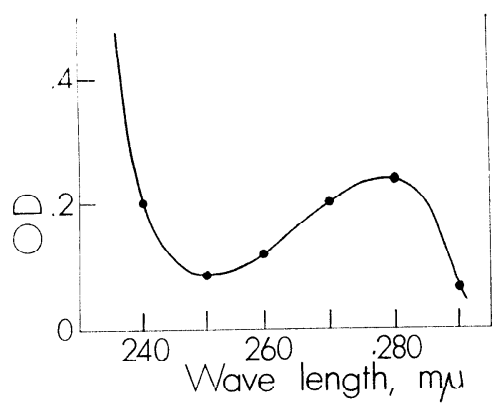

Fig. 6. The UV spectrum of the purest fraction (Step 8). The spectrum of the abnormal base line (Fig. 5) was deducted. was about 5.3 (Fig. 7). Effects of $\mathrm{NaCl}, \mathrm{MgCl}_{2}$ and EDTA on activity of the purest fraction were insignificant at the concentrations studied (Fig. 8). The irregularities of the values might be due to the unstability of the enzyme (see below). Table 2 indicates the effect of various substances. The effect of $\mathrm{pH}$ on stability was tested and the results of four experiments, collected in Fig. 9, gave two peaks (near $\mathrm{pH}$ 5 and 8 ). The valley between the peaks varied significantly from one experiment to another. To see whether this phenomenon was caused
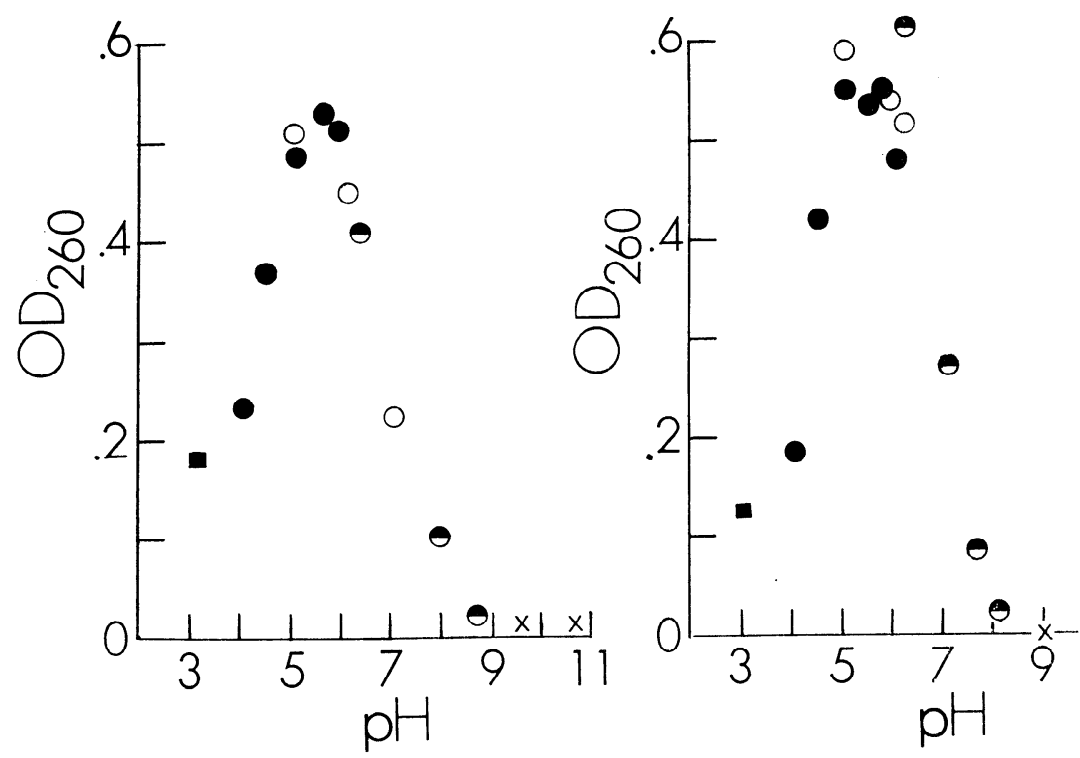

Fig. 7. The pH optimum of the purest fraction (right) and the crude extract (left). The assay procedure was the same as described in "Experimental" except the buffer solutions: $\square$, sodium acetate- $\mathrm{HCl}$;

$\bigcirc$, Tris-acetate ; $\odot \ominus$, Tris- $\mathrm{HCl} ; \times \times$, glycine- $\mathrm{NaOH}$. 
Table 2. Influcnce of various substances on the activity of the purest fraction. The assay was the same as mentioned in "Experimental" except the addition of substance solutions, which had been previously adjusted, if required, to $\mathrm{pH}$ 5.3. No reactivation was observed.

\begin{tabular}{|c|c|c|c|c|c|}
\hline Substance ${ }^{\mathrm{a}}$ & Effect & $\begin{array}{l}\text { Appearance } \\
\text { during } \\
\text { incubation }\end{array}$ & Substance ${ }^{\mathbf{a}}$ & Effect & $\begin{array}{l}\text { Appearance } \\
\text { during } \\
\text { incubation }\end{array}$ \\
\hline Glycine & $-\mathrm{b}$ & & $\mathrm{CH}_{2} \mathrm{ICOOH}$ & $-\mathrm{b}$ & \\
\hline Tricthanolaminc & - & & $\mathrm{NaCN}$ & & \\
\hline Tris-acetate & - & & $\mathrm{CySH}-\mathrm{HCl}$ & - & \\
\hline Sodium phosphate & e - & & $\mathrm{CaCl}_{2}$ & - & \\
\hline Sodium arsenate & - & & $\mathrm{BaCl}_{2}$ & - & \\
\hline Sodium arsenite & - & & $\mathrm{MnSO}_{4}$ & $t^{\mathrm{e}}$ & \\
\hline PCMB & - & not soluble & $\mathrm{ZnCl}_{2}$ & $++^{\mathrm{d}}$ & \\
\hline Phenylhydrazine & - & yellow & $\mathrm{FeCl}_{8}$ & ++ & turbid, yellow \\
\hline Thio urea & - & & $\mathrm{FeSO}_{4}$ & ++ & turbid, yellow \\
\hline $\mathrm{NH}_{2} \mathrm{OH}-\mathrm{HCl}$ & - & & $\mathrm{CuSO}_{4}$ & $+t$ & \\
\hline $\mathrm{NaHSO}_{3}$ & $t^{\mathrm{c}}$ & & $\mathrm{SnCl}_{2}$ & ++ & turbid \\
\hline $\mathrm{Na}_{2} \mathrm{SO}_{4}$ & - & & $\mathrm{AgCl}$ & ++ & ppl formed \\
\hline $\mathrm{NaF}$ & - & & & & \\
\hline
\end{tabular}

a Final concentration of the substances was $0.001 \mathrm{M}$.

b No effect.

c Partial inhibition.

d Complete inhibition.

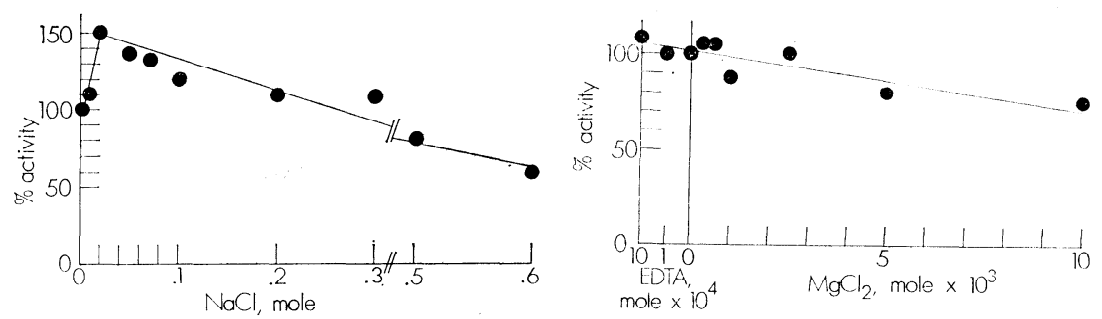

Fig. 8. Effect of various concentrations of $\mathrm{MgCl}_{2}$, EDTA (right) and $\mathrm{NaCl}$ (left) on the activity of the purest fraction. The assay was the same as described in "Experimental" except the addition of the substances, the amounts of which were indicaled by final concentrations in the assay mixtures.

by inactivation of the enzyme during dilution or not, the proportionality of $\mathrm{OD}_{260 \mathrm{~m}, u}$ to the enzyme concentration was checked. Fig. 1 (right) shows that the enzyme was practically stable, but the deviation of the value was a little more pronounced than that of the crude extract (Fig. 1, left). Thus, it cannot be concluded yet that the double peak of pH stability curve (Fig. 9) was caused by the heterogeneity of the enzyme. 


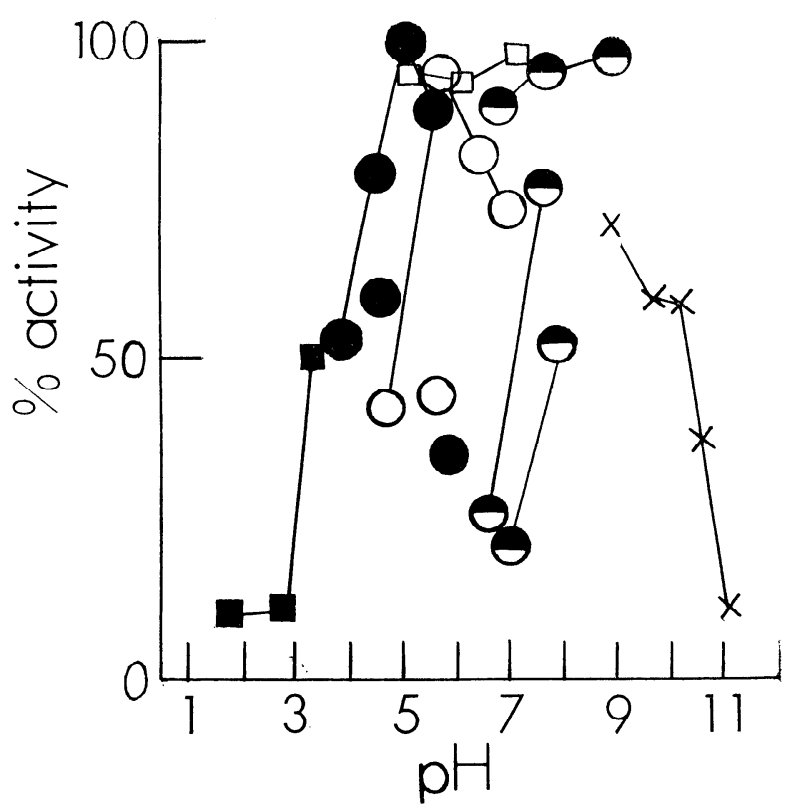

Fig. 9. Effect of pH on stability of the purest fraction. Aliquots $(0.2 \mathrm{ml})$ of a 10 -fold dilution of the sample were mixed with 0.25 or $0.5 \mathrm{M}$ buffers of various $\mathrm{pH}$ to attain $0.1 \mathrm{M}$ solution and kept $37^{\circ} \mathrm{C}$ for 17 hours with one drop of $\mathrm{CIICl}_{3}$. Buffers used: $-\mathbf{\square}$, sodium acetate$\mathrm{HCl}$; - - sodium acetate; $\bigcirc-\bigcirc$, Tris-acetate; $\odot-\Theta$, Tris-HCl; $X-X$, glycine-NaOH; $\square-\square$, sodium phosphate. The mixture were then diluted to $8 \mathrm{ml}$ by $0.2 \mathrm{M} \mathrm{NaCl}$ and the activities were compared with that of a control sample which had been kept frozen. The assay was donc according to "Experimental."

Fig. 10 shows the effect of heating on the stability of the Dowex 2 fraction (step 6). The diluted Dowex 2 fraction $\left(\mathrm{E}_{230}: 0.015\right)$ lost $90 \%$ of its activity after treatment with $0.25 \mathrm{~N} \mathrm{H}_{2} \mathrm{SO}_{4}$ (20 hours, at refrigerator temp, ca $\left.5^{\circ} \mathrm{C}\right)$. Storage of the crude extract $\left(\mathrm{E}_{280}: 84\right)$ at $-20^{\circ} \mathrm{C}$ for 9 months resulted in no loss of activity. The purest fraction $\left(\mathrm{E}_{230}\right.$ : 0.2) was stable during several cycles of thawing and freezing. A 10fold diluted solution of the purest fraction lost $50 \%$ of activity after 3 cycles of thawing and freezing.

The specific activity of the purest fraction (Step 8) was $1 / 4$ and $1 / 2.5$ of RNase $I$ and $T_{1}$ respectively (the former: N. B. C., after storage in $0.26 \mathrm{mg}$ per $\mathrm{ml}$ solution at $-20^{\circ} \mathrm{C}$ for over a year; the latter: Sankyo, freshly dissolved), although the Rhizopus enzyme hydrolyzes RNA completely (see below) while the other two incompletely, leaving cores. 
Limited yield of the purest protein did not allow ultracentrifuge analysis with sufficient accuracy. Unreliable data were omitted.

\section{Contaminating enzymes}

The Sephadex G-100 filtrate (Step 4) was found practically free from non-specific acid and alkaline PDase. Neither intact nor denatured thymus DNA was hydrolyzed to acid soluble fragments by 19 units of the enzyme fraction per $\mathrm{mg}$ substrate (in $0.125 \mathrm{M}$ Tris- $\mathrm{HCl}$ or acetate buffer, $\mathrm{pH} 7.5$ or 5.3 respectively, for $15 \mathrm{~min}$ at $37^{\circ} \mathrm{C}$ ). Non-specific PMase and 3'(2')-adenylic nucleotidase were detected even in the purest fraction (Step 8). The RNase/PMase ratio increased as the purification advanced. Deaminase activity was not chromatographically detectable (with Solvent 1) in the purest fraction (Step 8) with following substrates: adenosine, adenine, guanosine, guanine, cytosine, and cytidine. Liberation of nucleosides from adenosine 3'(2')-phosphate and guanosine 3'-phosphate was seen by paper chromatography with Solvent 1.

\section{Digestion of RNA}

Since the PMase and the nucleotidases were found completely in-

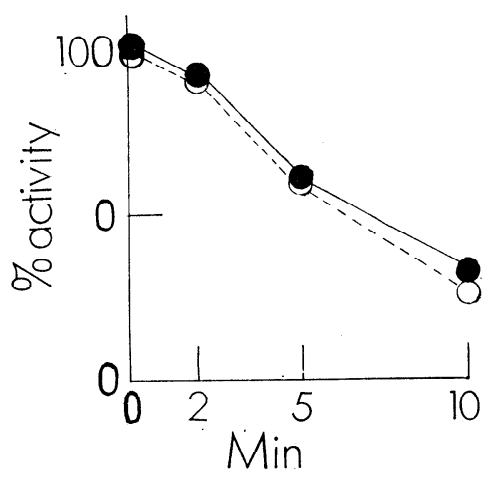

Fig 10. Effect of heationg on activity of the Dowex 2 fraction (Step 6). An aliquot $(0.2 \mathrm{ml})$ of the sample was adjusted to about $\mathrm{pH} 5.5$ by adding $0.5 \mathrm{~N}$ acetic acid and mixed with 5 $\mathrm{ml}$ of $0.14 \mathrm{M}$ sodium acetate buffer, pH 5.5 ( $\bigcirc-\bigcirc)$. Another aliquot was treated similarly with $0.14 \mathrm{M}$ Tris- $\mathrm{HCl}, \mathrm{pH}$ 8.0 (-). Each was immersed in boiling water bath for varying period and transferred to ice bath. The assay was carried out as described in "Experimental."

\section{hibited by arsenate, the analysis of}

specificity was possible. Purified yeast $\mathrm{RN} \Lambda$ (32 $\mathrm{mg})$ was incubated at $37^{\circ} \mathrm{C}$ for 20 hours with $3.2 \mathrm{ml}$ of the ECTEOLA-cellulose fraction (Step 5, 8 units of activity per $\mathrm{mg}$ of RNA), $0.05 \mathrm{M}$ (final) ammonium acetate buffer, $\mathrm{pH} 5.3$, and $0.007 \mathrm{M}$ (final) sodium arsenate. After incubation, a slight turbidity was centrifuged off, and an aliquot (3 $\mathrm{mg}$ of RNA) of the supernatant was mapped as described in "Experimental." Common four kinds of 3'(2')-mononucleotide and 2', 3'cyclic nucleotide, and traces of unidentified substances were found on the map (Fig. 11). Absence of oligonucleotide indicated the rapid, nonspecific hydrolysis of phosphodiester bonds at 5'-position in the polynucleotide chain. 

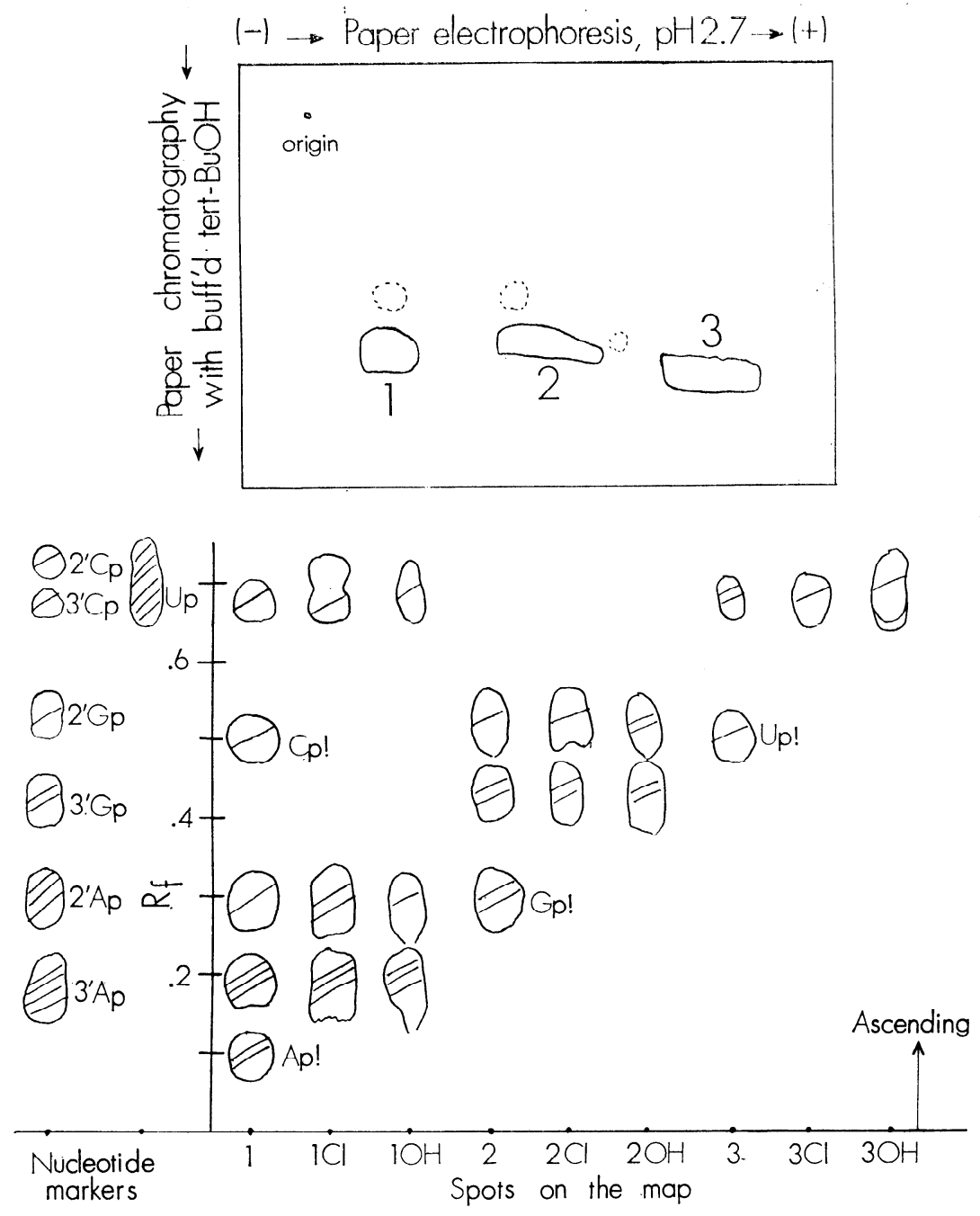

Fig. 11. (top)-Map of $3 \mathrm{mg}$ RNA digested by the Rhizopus RNase. The procedure was described in "Experimental". (bottom)-Paper chromatography (Solvent 1 ) of the water-eluted substances from the map. The marks $\mathrm{Cl}$ and $\mathrm{OH}$ indicate the $\mathrm{HCl}$ - and $\mathrm{NaOH}$-treatment of the water-eluate respectively (see "Experimental"). Thus, the identification of the spots on the map : 1, Cp, Cp!, Ap and Ap!; 2, Gp and Gp! ; 3, Up and Up!.

\section{Digestion of cyclic nucleotides}

Assay of cyclic PDase activity was carried out as follows: the digest of RNA as well as an acid-treated aliquot of the digest was chromatographed in Solvent 2 (Fig. 12). The spots which disappeared 
when the sample was treated with $0.1 \mathrm{~N} \mathrm{HCl}$ should be cyclic nucleotides, and so were cluted by water and incubated with Rhizopus enzyme (the ECTEOLA-cellulose fraction, Step 5). This time, arsenate was not added. The mixtures were then subjected to paper chromatography with Solvent 1 . Although absence of arsenate in the incubation mixture caused the degradation of nucleotide to nucleoside, it ran close to the corresponding 3'-nucleotide in Solvent 1 and the molecular extinction coefficient is the same for both. ${ }^{22)}$ So there is no trouble. Fig. 13 shows that the resulting purine nucleotides were 3 '-isomers. The position of phosphorus in the resulting pyrimidine nucleotides was not identifiable. The separated spots were eluted with $0.1 \mathrm{~N} \mathrm{HCl}$ and

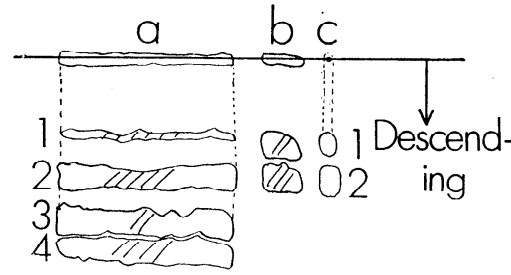

a: RNase digest of RNA 1: Gp, 2: Ap, Cp b: HCl-treated digest \& Up, 3:Gp !, 4: c: Nucleotide markers Ap!,Cp!\& Up

Fig. 12. Paper chromatography in Solvent 2 of RNA (14 mg) digested by the RNase and an acidtreated aliquot of the digest. Spots 3 and 4 were cut out and eluted with water. the rate of conversion of cyclic nucleotide to monophosphate was determined spcctrophotometrically (Table 3). The order of apparent preference of the cyclic PDase activities toward four substrates was Ap!, Gp! $>\mathrm{Up} !>\mathrm{Cp}$ !. A possibilty still remains that these activities might be due to non-specific cyclic PDase, in stead of the Rhizopus RNase itself.

Table 3. Comparison of cyclic nucleotidase activity of Rhizopus enzyme with those of RNase $I$ and $T_{1}$, deduced from the preceding paper chromatography (Fig. 13).

\begin{tabular}{|c|c|c|c|c|}
\hline \multirow[t]{2}{*}{ Enzyme } & \multicolumn{4}{|c|}{$\begin{array}{l}\% \text { mononucleotides resulting from } \\
\text { cyclic isomer }\end{array}$} \\
\hline & $\Lambda \mathrm{p}$ & $\mathrm{Gp}$ & $\mathrm{Cp}$ & $\mathrm{Up}$ \\
\hline Rhizopus enzyme & $100^{\mathrm{b}}$ & $100^{b}$ & $53^{a}$ & $90^{2}$ \\
\hline Pancreatic RNase I & $0^{b}$ & $-c$ & $95^{\mathrm{a}}$ & $93^{\mathrm{a}}$ \\
\hline Asp. oryzae RNase $\mathrm{T}_{1}$ & $-c$ & $100^{\mathrm{b}}$ & -e & $-\mathrm{c}$ \\
\hline
\end{tabular}

a The spots of cyclic and noncyclic pyrimidine nucleotides on the filter paper (Fig. 13) were eluted with $0.1 \mathrm{~N} \mathrm{HCl}$ overnight and the hydrolyses of cyclic phosphodiester bonds by the enzymes were quantified by spectrophotometry. Dual readings at 260 and $280 \mathrm{~m} \mu^{13}$ ) were necessary, since $\mathrm{Cp}$ and $\mathrm{Up}$ are not separated (also Cp! and Up!) by Solvent 1.

b Quantitative measurement was not performed; apparently $100 \%$ or $0 \%$ as shown by the paper chromatography (Fig. 13).

c No experiment was done. 


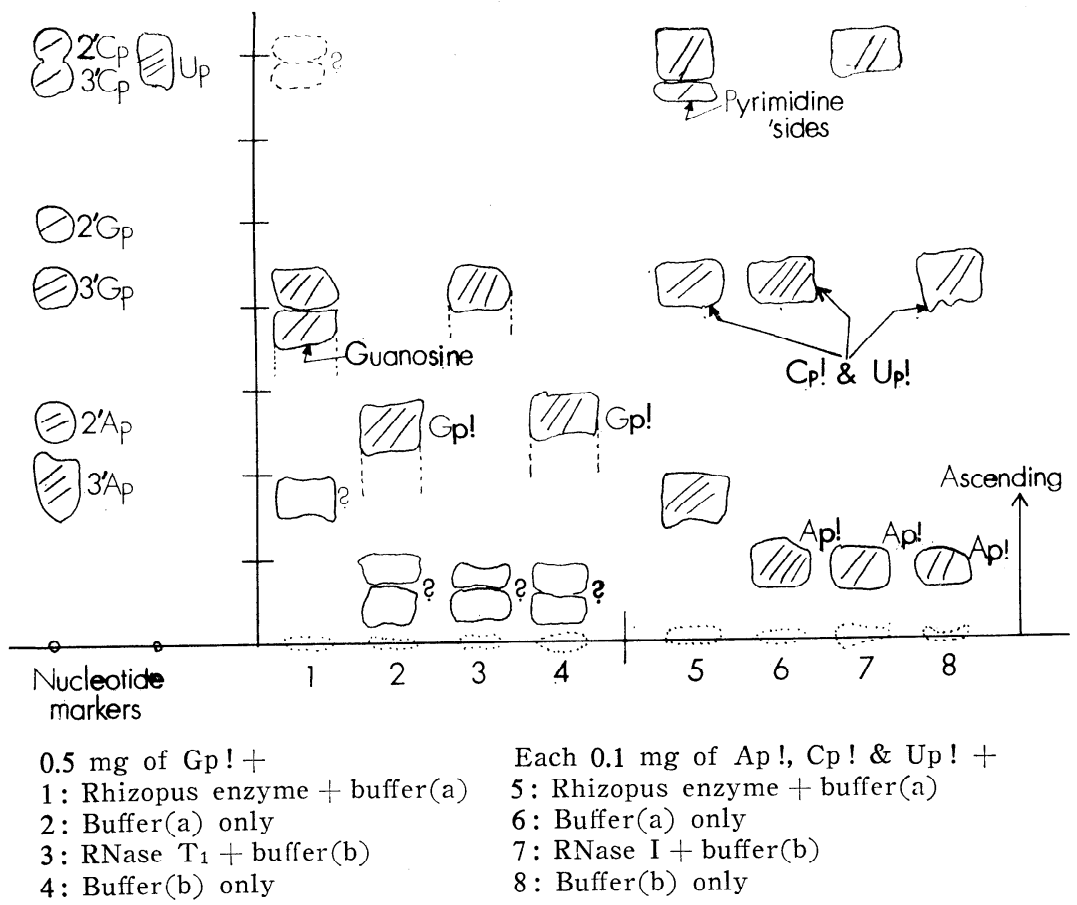

Fig. 13. Comparison of cyclic PDase activities of the Rhizopus enzyme fraction (Step 5) with RNase I and RNase $T_{1}$. Substrates obtained chromatographically (Fig. 12) were Gp! and a mixture of Ap!, Cp! and Up!, and these were digested by the enzymes. For convenience the treatment was performed at the optimum $\mathrm{pH}$ of RNase activity, not of cyclic PDase activity. Buffers used were (a) $0.05 \mathrm{M}$ (final) of ammonium acetate buffer, $\mathrm{pH}$

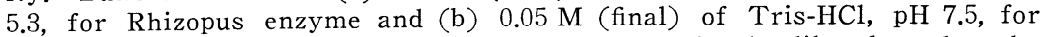
RNase I and $T_{1}$. The last two enzymes were previously diluted so that the same RNase units per $\mathrm{ml}$ could be employed as that of the Rhizopus enzyme fraction. Reaction conditions: 8 units per mg substrate, 48 hours, at $37^{\circ} \mathrm{C}$, without arsenate. The mixtures were then chromatographed with Solvent 1. Absence of arsenate in Rhizopus enzyme caused formation of nucleosides, which could be detected and computed as equivalent to 3'-nucleotides, making no difference as to the specificity of the cyclic PDase studied (see text).

\section{DISCUSSION}

The Rhizopus RNase (the Sephadex G-100 filtrate, Step 4) was not retained by CM-cellulose in equilibrium with $0.02 \mathrm{M}$ ammonium acetate buffer, pH 5.5. On the contrary, the enzyme was irreversibly adsorbed

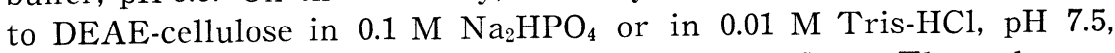
the column being shrinked to prevent the buffer flow. Thus, the use 
of a more weakly basic ion-exchanger seemed promising, and the ECTEOLA-celluose chromatography (Fig. 3) exhibited a sharp peak of activity, giving a remarkable increase of specific activity. But, the curves of $\mathrm{pH}$ and chloride concentration showed steep inflections. The elution of the active protein was, therefore, not of an ideally gradient nature. It has been reported that anion exchangers often give complicated elution patterns; for example, the displacement chromatography was studied by Boman and Westlund, ${ }^{5)}$ where several proteins split into two at the steep chloride front. Other example was studied by Björk,3) who reported that when working with anion exchangers at an alkaline $\mathrm{pH}$, some interaction with atmospheric $\mathrm{CO}_{2}$ cannot be avoided, and sometimes results in an artifact of a protein chromatography. In the case of the Rhizopus enzyme, the chromatography (Fig. 3) was performed in relatively low $\mathrm{pH}$ level, but presumably some element influenced and complicated the mechanism of elution of the active protein. A more suitable condition of the chromatography remains to be searched.

Turning to the cyclic nucleotides, they are the intermediary products of RNA hydrolysis with alkali and pancreatic RNase I. $^{6}$ If the formation of 2', 3'-cyclic nucleotides might be an inherent property of many RNases, ${ }^{9)}$ it may be concluded that the Rhizopus enzyme has a "RNase" activity, because it forms cyclic nucleotides (Fig. 11). It also exhibits cyclic PDase activities (Fig. 13). As for the crystalline pancreatic RNase IA, the cyclic pyrimidine nucleotidase activity is the nature of the enzyme itself. It may be remarked here that the rat liver alkaline RNase seems to have no ability to hydrolyze cyclic nucleotides. ${ }^{26.41)}$ And the RNases from tobacco leaf ${ }^{25)}$ and pea leaf ${ }^{15)}$ do not split cyclic pyrimidine nucleotides, although they have no specificity as to hydrolysis of internucleotide linkages. These facts lead to a remaining probability that the cyclic PDase activities of Rhizopus enzyme fraction might be due to some contaminant. The enzyme, however, was found free from Ca-bis (para-nitrophenyl) phosphatase activity. Existence of other PDases which attack cyclic nucleotides can not be ruled out yet.

Although cyclic nucleotide preparations are necessary for studies of nucleases, they are unstable and it is difficult to preserve. Even in Basalt they are slowly converted to '2'(3')-phosphates. ${ }^{38)}$ Since the cyclic PDase action of the Rhizopus enzyme is relatively slow, preparation of cyclic nucleotides is facilitated by use of our Rhizopus enzyme; when the RNase digest of RNA is chromatographed in Solvent 2, a mixture of Ap!, Up! and $\mathrm{Cp}$ ! is obtained in one spot, and $\mathrm{Gp}$ ! alone separately. If the digestion of RNA is carried out with the enzyme and pancreatic RNase I, then Ap! will be singly obtained.

The data presented here show that partially purified Rhizopus en- 
zyme exhibits non-specific RNase and cyclic PDase activities, still contaminated with nonspecific PMase or nucleotidases. Further purification is desircd. The mode of action of the RNase should be studied by use of RNase $\mathrm{I}$ - and $\mathrm{T}_{1}$-cores (exonucleolytic or endonucleolytic). Some information about the molecular weight of this enzyme will be obtained by analytical gel filtration ${ }^{1,40}$ ) or ultracentrifugation.

\section{SUMMARY}

Rhizopus RNase was purified 1000-fold from Glutase with a yield of $2.3 \%$. It was most active between pH 5 and 5.5. The enzyme appeared not homogeneous in the analytical gel filtration through Sephadex G-100. The enzyme was free from DNase and PDase. Nucleotidases were found, which were inhibited by arsenate. The hydrolytic specificity of the enzyme action was examined by characterization of the digest of yeast RNA. The enzyme produces four kinds of 2', 3'-cyclic nucleotides, which are slowly hydrolyzed to the corresponding mononucleotides. The cyclic PDase activities showed a preference for cyclic purine nucleotides, and the action for cyclic pyrimidine nucleotides seemed to be slower than that of RNase I. The Rhizopus RNase is useful for preparation of cyclic nucleotides. Further purification is needed for the additional characterization of the enzyme.

\section{ACKNOWLEDGMENT}

The authors are thankful to Mr. Takagi of Hankyu Enzyme Co. for supplying Glutase and for much advice.

\section{ABBREviATIONS}

RNA : ribonucleic acid, RNase: ribonuclease, DNase : deoxyribonuclease, PDase: phosphodiesterase, PMase: phosphomonoesterase ; Ap, $\mathrm{Gp}, \mathrm{Cp}$, and Up: adenosine, guanosine, cytidine, and uridine 2'- or 3'phosphate respectively. Cyclic 2', 3'-phosphates are represented by the symbol "!." Thus, Ap! is adenosine 2, 3'-cyclic phosphate.

\section{REFERENCES}

1) Auricchio, F. and C. B. Bruni, Biochem. Z., 340, 321 (1964).

2) Beaven, G. H., E. R. Holiday and E. A. Johnson, The Nucleic Acids, I, p. 493 (E. Chargaff and J. N. Davidson, Eds.) Academic Press, 1955.

3) Björk, W., J. Chromatog., 8, 479 (1962).

4) Björk, W., J. Biol. Chem., 238, 2487 (1963). 
5) Boman, H. G. and L. E. Westlund, Arch. Biochem. Biophys., 70, 572 (1957).

6) Brown, D. M. and A. R. Todd, The Nucleic Acids, I, p. 409 (E. Chargaff and J. N. Davidson, Eds.) Academic Press, 1955.

7) Edmonds, M. and J. S. Roth, Arch. Biochem. Biophys., 89, 207 (1960).

8) Glitz, D. G. and C. A. Dekker, Biochemistry, 3, 1391 (1964).

9) Josefsson, L. and S. Lagerstedt, Methods of Biochemical Analysis, IX, p. 39 (D. Glick, Ed.) John Wiley \& Sons, 1962.

10) Kakinuma, A., S. Igarasi and K. Ogata, Agr. Biol. Chem., 26, 213 (1962).

11) Kaplan, H. S. and L. A. Heppel, J. Biol. Chem., 222, 907 (1956).

12) Kawaguchi, K. and T. Kojima, Nogei-kagaku Jikken-sho, I, p. 105 (T. Mitsui, H. Mitsuda and T. Hata, Eds.) Sangyo Tosho, 1957.

13) Loring, H. S., The Nucleic Acids, I, p. 199 (E. Chargaff and J. N. Davidson, Eds.) Academic Press, 1955.

14) Markham, R. and J. D. Smith, Biochem. J., 52, 552, 558 (1952).

15) Markham, R. and J. L. Strominger, Biochem. J., 64, 46p (1956).

16) Maver, M. E. and A. E. Greco, J. Biol Chem., 237, 736 (1962).

17) McCully, K. S. and G. L. Cantoni, Biochim. Biophys. Acta, 51, SC190 (1961).

18) Nakao, Y. and K. Ogata, Agr. Biol. Chem., 27, 116, 291, 499 (1963).

19) Nakao, Y., I. Nogami, K. Ogata, Agr. Biol. Chem., 27, 507 (1963).

20) Naoi-Tada, M., K. Sato-Asano and F. Egami, J. Biochem., 46, 757 (1959).

21) Nishimura, S., Biochim. Biophys. Acta, 45, 15 (1960).

22) Nodes, J. T., Biochim. Biophys. Acta, 32, SC551 (1959).

23) Ogata, K., Y. Nakao, S. Igarasi, E. Omura, Y. Sugino, M. Yoneda and I. Suhara, Agr. Biol. Chem., 27, 110 (1963).

24) Osaka, A., J. Mukai and M. Laskowski, J. Biol. Chem., 239, 3198 (1961).

25) Reddi, K. K., Biochim. Biophys. Acta, 28, 386 (1958) ; 30, 638 (1958).

26) Reid, E. and J. T. Nodes, Ann. N. Y. Acad. Sci., 81, 618 (1959).

27) Rushizky, G. W. and C. A. Knight, Virology, 11, 236 (1960).

28) Rushizky, G. W. and H. A. Sober, J. Biol. Chem., 237, 834, 2883 (1962).

29) Rushizky, G. W. and H. A. Sober, J. Biol. Chem., 238, 371 (1963).

30) Rushizky, G. W., A. E. Greco, R. W. Hartley and H. A. Sober, Biochemistry, 2, 787 (1963).

31) Rushizky, G. W., A. E. Greco, R. W. Hartley and H. A. Sober, J. Biol. Chem., 239, 2165 (1964).

32) Sato, K. and F. Egami, J. Biochem., 44, 753 (1957).

33) Sato-Asano, K., J. Biochem., 46, 31 (1959).

34) Sevag, M. G., D. B. Lackman and J. Smolens, J. Biol. Chem., 124, 425 (1938).

35) Shuster, L., H. G. Khorana and L. A. Heppel, Biochim. Biophys. Acta, 33, 452 (1959).

36) Staehelin, M., Biochim. Biopys. Acta, 87, SC493 (1964).

37) Suhara, K., F. Kusaba, Y. Nakao and E. Omura, 11th Amino Acids and Nucleic Acids Symposium, 1964, Fukuoka.

38) Szer, W. and D. Shugar, Biochemical Preparations, X, p. 139 (G. B. Brown, Ed.) John Wiley \& Sons, 1963.

39) Tuve, T. W. and C. B. Anfinsen, J. Biol. Chem., 235, 3437 (1960).

40) Whitaker, J. R., Anal. Chem., 35, 1950 (1963).

41) Zytko, J., G. de Lamirande, C. Allard and $\Lambda$. Cantero, Biochim. Biophys. Acta, 27, 495 (1958). 